\title{
谷口奈緒美 学位論文審査要旨
}

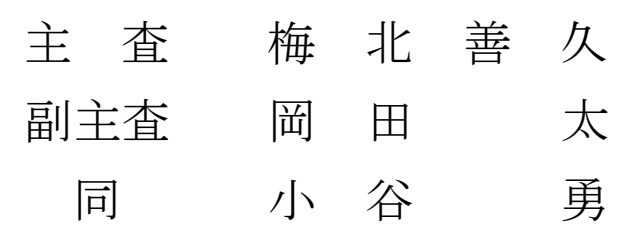

\section{主論文}

Bisphosphonates induced reactive oxygen species inhibit proliferation and migration of oral fibroblast: a pathogenesis of bisphosphonate-related osteonecrosis of the jaw

（ビスフォスフォネートが誘導する活性酸素は、口腔線維芽細胞の増殖と遊走を阻害す

$$
\text { る：顎のビスフォスフォネート関連骨壊死の病因） }
$$

(著者 : 谷口奈緒美、尾㠃充彦、小沼邦重、石川瑞穂、領家和男、小谷勇、岡田太) 令和2年 Journal of Periodontology 掲載予定

\section{参考論文}

1. Surgical ciliated cyst developing after Le Fort I osteotomy : case report and review of the literature

（ルフォー I 型骨切り術後に発生した外科的繊毛囊胞 : 症例報告と文献レビュー)

(著者 : 谷尾俊輔、田村隆之、加須屋浩、川嵪誠、谷口奈緒美、大月一真、藤井信行、 小谷勇)

令和元年 Journal of Oral and Maxillofacial Surgery, Medicine, and Pathology 31 巻 410 頁 $\sim 414$ 頁 


\section{審 査 結 果 の 要 旨}

本研究はビスフォスフォネート製剤に対するヒト歯周勒帯線維芽細胞と皮膚線維芽細胞 の違いを酸化ストレスの観点から解析し、ビスフォスフォネート関連顎骨壊死 (BRONJ) が 顎骨特異的に生じる原因を検討し、顎骨壊死マウスモデルを用いて活性酸素消去剂による 創傷治癒の改善効果を検証した。その結果、歯周勒帯線維芽細胞は皮膚線維芽細胞よりも ビスフォスフォネートに対する感受性が高く、ビスフォスフォネート処理による活性酸素 の増加は、歯周勒帯線維芽細胞の増殖と遊走能を低下させ、活性酸素消去剂の添加により 回復した。ビスフォスフォネート投与と抜歯による顎骨壊死マウスモデルにおいて、活性 酸素消去剂の投与は創傷治癒を改善した。本研究は、BRONJの病因として口腔内の線維芽細 胞に生じる酸化ストレスの関与を示し、BRONJの予防や治療に対する活性酸素消去剂の有用 性を示唆したものであり、明らかに学術水準を高めたものと認める。 